\title{
THE STRUCTURAL CONTROL OF THE GOLD DEPOSITS OF THE FAZENDA MARIA PRETA GOLD DISTRICT AT RIO ITAPICURU GREENSTONE BELT, NORTHEASTERN BRAZIL
}

\author{
CARLOS EDUARDO SILVA COELHO* \& FLÁVIO HENRIQUE FREITAS SILVA**
}

\begin{abstract}
RESUMO O CONTROLE ESTRUTURAL DOS DEPÓSITOS DE OURO DO DISTRITO AURÍFERO DE FAZENDA MARIA PRETA, GREENSTONE BELTDO RIO ITAPICURU, NORDESTE DO BRASIL O Distrito Aurífero de Fazenda Maria Preta compreende um grupo de depósitos individuais encaixados em zonas de cizalhamento, localizados na parte norte do greenstone belt Rio Itapicuru (GBRI), no nordeste do Brasil. Os depósitos estão inseridos na unidade Maria Preta, que corresponde a rochas de composição andesítica com intercalações piroclásticas e de rochas sedimentares e alguns corpos dacíticos e dioríticos, sendo o conjunto metamorfizado no fácies xisto verde. A deformação na área está caracterizada por uma bem desenvolvida foliação NS, mergulhando em torno $60^{\circ} \mathrm{W}$, com lineações de estiramento de baixo mergulho predominantemente para norte. As zonas onde essa foliação é mais intensamente desenvolvida (contatos litológicos) foram definidas como zonas de cisalhamento (ZS-I to IV). Em relação ao ambiente tectônico do GBRI, essas zonas correspondem a zonas de cizalhamento de $2 *$ ordem, paralelas à Zona Principal de Cizalhamento. Nessas zonas, os principais elementos estruturais observados foram foliacões miloníticas e lineações de estiramento. Esses elementos definem uma deformação transcorrente sinistrai gerada por uma componente de cisalhamento simples dominantemente não-coaxial, em domínios dúctil-frágeis à frágil-dúcteis, com movimentos subordinados oblíquo-reversos ou oblíquonormais. A análise dos indicadores cinemáticos determina um elipsóide de deformação finito oblato e deformação tectônica frágil a moderada. Os veios de quartzo mineralizados, encaixados nas zonas de cizalhamento, correspondem principalmente a veios de cizalhamento paralelos à foliação milonítica e, subordinamente, veios em extensão. Os corpos de minério apresentam uma geometria tabular, que constitui o controle primário da mineralização. O controle secundário é dado pela lineação de estiramento, a qual reorienta os corpos de minérios tabulares paralelamente ou perpendicularmente ao seu plunge. Os veios de quartzo são geralmente maciços ou brechados e texturas de preenchimento de espaços vazios são raras, indicando que as fraturas se separaram abruptamente devido a altas pressões de fluido. As relações de campo e as feições de deformação interna dos veios indicam que os mesmos foram formados ou encaixados em diferentes estágios durante o evento deformacional. O modelo de formação dos veios proposto para a área é análogo ao modelo fault-valve de Sibson et al. (1988).
\end{abstract}

Palavras-chave: mineralização aurífera, zonas de cizalhamento, elementos estruturais, veios de quartzo

ABSTRACT The Fazenda Maria Preta gold district comprises a group of individual shear-zone-hosted gold deposits located in the northern part of the Rio Itapicuru greenstone belt (RIGB), northeast Brazil. The deposits are limited to the Maria Preta unit, which is represented by rocks of andesitic composition with some interlayered pyroclastic and sedimentary rock lenses, and some dacitic and dioritic bodies, metamorphosed to the greenschist facies.

The deformation in the area is characterised by a well developed NS-trending foliation dipping around $60^{\circ} \mathrm{W}$, with an associated stretching lineation shallowly plunging predominantly towards the north. The zones where this foliation is more intensively developed (lithologic contacts) were defined as shear zones (SZ-I to IV). In relation to the tectonic setting of the RIGB these zones correspond to $2^{\mathrm{n}}$ order shear zones, parallel to the NS striking Main Shear Zone. In these zones, the main structural fabrics observed were mylonitic foliation and stretching lineation. These elements define a sinistral strike-slip deformation generated by a dominant non-coaxial simple shear component, within ductile-brittle to brittle-ductile domains, with minor oblique-reverse transpressive or oblique-normal transtensive motions. The analysis of the kinematic indicators determine an oblate finite strain ellipsoid and weak to moderate tectonic deformation.

The mineralized quartz veins, hosted in the shear zones, are mainly shear-type veins parallel to the mylonitic foliation, and minor extensional veins. The oreshoots present a tabular geometry, which constitute the primary control of the mineralization. A secondary control is the stretching lineation, which reorients the original tabular oreshoots parallel or perpendicular to its plunge. The quartz veins are generally massive or brecciated, and textures of open space filling are rare, indicating that the fractures jacked apart abruptly due to high fluid pressure. The field relations and the internal deformation features of the veins indicate that they were formed or emplaced at different stages during the deformation event. The model of emplacement of the veins proposed for the area, is analogous to the fault-valve model of Sibson et al. (1988).

Keywords: gold mineralization, shear zones, structural elements, quartz veins

INTRODUCTION Several det alled structural studies in gold deposits situated in deformed zones of greestone belts terranes, carried out in the last 10 years (see references in Robert et al. 7990 and Robert \& Poulsen, 1994), have demonstred that the distribution of the deposits in those terranes is controled by ductil kilometer long oblique or strike parallel shear zones, which can represent reactivation of crustal fractures in collision context. Those zones served as conduits for shallow granitoids, felsic porphyries, calc-alkaline lamprophyres and mineralizing fluids. However, such structures, considered as first-order shear zones, are not economically mineralized. The economic mineralizations are found generally in ductile to brittle shear zones of local scale, corresponding to second- or third-order structures of metric width and about $10 \mathrm{~km}$ in length.

In this paper, a review of the structural existing data, complemented by new ones about the structure of the gold deposits in the Fazenda Maria Preta (FMP) gold district is presented. The aim of this study is to describe and discuss the main structural features that control the shear zone-hosted gold mineralization at FMP based mainly on det alled observations of several open pit exposures along with their structural setting in relation to the tectonic evolution of the greenstone-belt.

REGIONAL GEOLOGIC SETTING The Fazenda Maria Preta (FMP) district is localized in the northern part of the Rio Itapicuru Greenstone Belt (RIGB), in north-eastern Brazil, State of Bahia, which is part of the São Francisco Cráton supracrustal sequences (Fig. 1). The geology is dominated by Lower Proterozoic tholeiitic basalts, calc-alkaline volcanics and volcanic-derived sediments, metamorphosed to greenschist facies (Kishida \& Riccio 1980). Sm-Nd and $\mathrm{Pb}-\mathrm{Pb}$ dating indicate an age of around $2.1 \mathrm{Ga}$. for the meta-volcanic rocks (Gáal et al. 1987, Silva 1987). The RIGB tectonic evolution, defined by Alves da Silva (1995), corresponds to the closing of a volcano-sedimentary basin as result of a NW-SE shortening, and which involved two main deformational events: D1 (horizontal tectonic - thrusts) and D2 (vertical tectonic - diapirism of granitic domes). The analysis of the finite deformation demonstrated the existence of a increasing deformation gradient from $\mathrm{W}$ to $\mathrm{E}$, attaining a maximum magnitude along a NS belt, named as Main Shear Zone and interpreted as a relict of a crustal scale thrust zone, which controlled the closing of the basin (Alves da Silva 1995). The interpretation of Landsat image in the scale of the RIGB (Yamakawa et al. 1993) also demonstred the existence of this major NS structure (MSZ) as well as others parallel discontinuities. In this work this belt is considered as the first-order shear zone.

The area consists of three major lithostratigraphic sequences. From W to E, they are (Fig.2): (a) the Rebolo Unit, made up of basalts with minor intercalated sedimentary rocks; (b) the Maria Preta Unit, composed of andesites, agglomerates, tuffs, pelites, dacites and, diorites; and the Riacho Seco Unit, made up of turbiditic psammites and pelites (Alves da Silva \& Matos 1991).

The area is characterized by a penetrative foliation, $S_{1}$, striking NS and dipping between $50^{\circ}$ to $70^{\circ} \mathrm{W}$ with an elongation lineation plunging shallowly $\left(10^{\circ}-20^{\circ}\right)$ either to the north or to the south (Fig. 3a Freitas-Silva \& Coelho 1993). All the deposits of the FMP district (quartz veins -Fig. 3b) occur in zones of more intense foliation, parallel to the regional foliation, developed mainly along the contact between different lithologies, defined as shear zones. In general, is very difficult to distinguish the structural elements of the shear zone from those of the regional deformation event, which arise the problem about the real significance of these zones. However, according to Robert (1992), the

* Universidade Federal da Bahia/Centro de Pesquisa em Geofísica e Geologia. Rua Caetano Moura, 123 - Federação, Salvador, Brazil. Cep: 40.210-340. e-mail: ccoelho@pppg.ufba.br

** Universidade de Brasília, Institute de Geociências, Brasília-DF, Brazil - Cep: 70.910-900. 
development of compositional layering in different rock types within these zones is a good criterion to characterize them as typical shear zones.

GENERAL CHARACTERISTICS OF THE FAZENDA MARIA PRETA (FMP) GOLD DISTRICT In this paper, the Fazenda Maria Preta gold district is considered as the group of small deposits which are hosted in the northern portion of the belt and includes Antas I, Antas II, Antas III, W, Mari, Cl, Cl-North, M-l and M-l 1 deposits.

All deposits occur in the Maria Preta Unit, and are associated with three parallel N-S striking shear zones, developed mainly along lithologic contacts. The shear zone I (SZ-I) contains from north to south C-1 North, C-1, Antas I, W, and Antas III (Fig. 2). The shear zone II (SZ-II) includes only Antas II deposit (Fig. 2). The shear zone IV (SZ-IV) present from north to south the open pits of Mari (Cl-A and $\mathrm{C} 2 / \mathrm{C} 3$ orebodies), M-1l and M-1 (Fig. 2). The shear zone III is localized in the western part of the area (outside figure 2), and does not contain any known economic deposit. Considering that the MSZ represents a first order shear zone, the deposits of the FMP district are situated within second order shear zones, parallel to the MSZ.

The mineralization comprises predominantly quartz veins and their brecciated and veined host rocks (mainly carbonaceous schist and
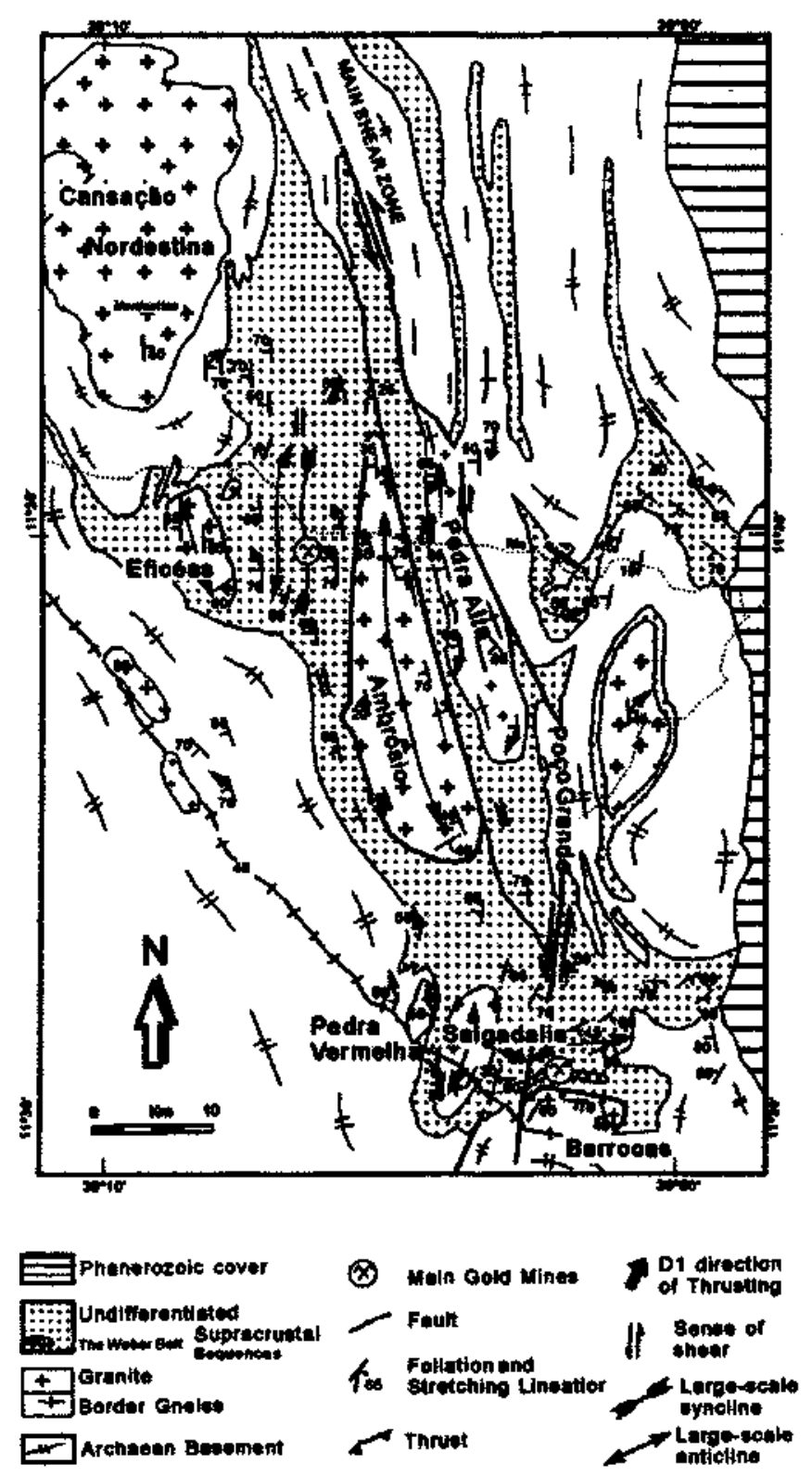

Figure 1 - Geologic map of the Rio Itapicuru Greenstone Belt. After Alves da Silva (1995). meta-dacite, and minor meta-sediment, meta-andesite, and meta-gabbro).

The quartz veins are texturally divided into two types: (i) "breccia" veins; and (ii) "massive" veins. "Breccia" veins are made up of angular fragments of host rocks (meta-dacite with stockwork or carbonaceous schist) of variable dimensions $(1$ to $30 \mathrm{~cm})$ and which do not show evidence of rotation; in thin section, they show little or no evidence of deformation. The "massive" designation is used when the fragments are less than 10\%; however, in some deposits, like M-1l, the mineralization consists of quite different massive smoky quartz veins. The veins are composed predominantly of quartz, but some orebodies are represented by quartz-carbonate veins.

Mineralized wall rocks, restricted to envelopes bordering the mineralized veins, are generally carbonatized, silicified, brecciated and veined; this close association between veins and brecciated and veined wall rocks indicate that they belong to the same mineralizing event.

Another type of mineralization is represented by low grade (around $0.7 \mathrm{ppm}$ in average) silicified and albitized pyrite-and carbonate bearing dacite, cut by a network of quartz veinlets, which gives an aspect of stockwork; this type of ore is restricted to the dacitic body. A summary of the main characteristics of each gold deposit is presented in table I.

STRUCTURAL CHARACTERIZATION OF THE FMP GOLD

DISTRICT In order to characterize the structural framework of the Fazenda Maria Preta district, a det alled study of the structural elements observed in the open pits, prospects, and in the Itapicuru river section was carried out. The internal structure and kinematics of the shear zones will be examined, except for the fractures and veins which will be analyzed later.

As cited above, in the FMP gold district three shear zones host the major orebodies. The SZ-I is traced over a distance of $15 \mathrm{~km}$ and 10 to $100 \mathrm{~m}$ wide (Fig. 2). The SZ-II, localized at west of ZC-I (Fig. 2), is $20 \mathrm{~km}$ long and less than $150 \mathrm{~m}$ wide. The SZ-IV, localized in the eastern portion of the area (Fig. 2), is $30 \mathrm{~km}$ in strike length and has an average with of $70 \mathrm{~m}$ (Alves da Silva \& Mates 1991). These shear zones are subparallel in strike and dip: they are oriented N-S and dips at about $50^{\circ}$ to $70^{\circ} \mathrm{W}$. Thus, on the basis of the scale and in relation to the MSZ, they are second order.

The penetrative foliation and elongation lineation within these shear zones are parallel in strike and dip to the regional foliation $(\mathrm{Sj})$ and elongation lineation (L,), as mentioned above (see figure $3 \mathrm{a}$ ). In order to differentiate the structural fabrics of the shear zones, their penetrative foliation and stretching lineation are referred here as Sm and Lst respectively.

Structural Characterization of Shear Zone-I (SZ-I) Based on det alled observations in the open pits of Antas III, Antas II, Cl, and $\mathrm{C} 1$-North deposits and in the outcrops along the margin of the Itapicuru river (station $\mathrm{n}^{\circ} 3$ in figure 2), SZ-I is defined by a major planar anisotropy (mylonitic foliation - Sm) with a direction at about N-S, and dipping varying from $50^{\circ}$ to $65^{\circ} \mathrm{W}$.

The SZ-I presents, at surface, a characteristic anastomosed pattern. At Antas I and $\mathrm{Cl}$ deposits, large-scale pods of meta-dacites and meta-diorites respectively, enveloped by zones of intense foliation, characterize this anastomosed pattern. At Antas III deposit this pattern is best observed in the dacitic body, where the shear zone rocks constitute decametric zones of schist, whereas the less deformed zones present a massive aspect with a well developed fracture pattern.

ITAPICURU RIVER STATION In the outcrops of dacitic agglomerates $\left(\mathrm{n}^{\circ} 3\right.$, Fig. 2) an observed intense penetrative foliation strikes $\mathrm{N} 17^{\circ} \mathrm{E} / 54^{\circ} \mathrm{NW}$ (Fig. 4a). The bomb- and lapilli-sized fragments, immersed in a matrix of lapilli tuff, are strongly stretched; they define a stretching lineation which plunges from horizontal to $257 \mathrm{~N} 10^{\circ} \mathrm{W}$ (Fig. 4a).

ANTAS I/C1/C1-NORTH DEPOSITS In the open-pits of these deposits, the mylonitic foliation presents a relatively constant N-S direction, and dips at about $64^{\circ} \mathrm{W}$. Stretching lineation (Lst), locally parallel to mineral lineation (Lmi), plunges on average at $25^{\circ}$ to the north (Fig $4 b)$. Sedimentary bedding $\left(S_{0}\right)$, preserved in low-strained zones within the $\mathrm{Cl}$ open-pit, exhibits open to tight $\mathrm{F}_{t}$ upright folds with the mylonitic foliation as axial planes. F! fold axes $\left(\mathrm{L}_{1}\right)$, parallel to the intersection lineation $\mathrm{S}_{0}$ vs. Sm (Fig. $4 \mathrm{c}$ ), present the same attitute as the stretching lineation (Lst).

ANTAS III DEPOSIT In the northern portion of the Antas III deposit (H Orebody) the mylonitic foliation (Sm) strikes $01^{\circ}$ to north-east and 
dips $54^{\circ} \mathrm{NW}$ (Fig. 4d). This penetrative foliation commonly contains an elongation lineation which corresponds to a mineral lineation or to the stretching lineation represented by elongated fragments in the tuff; this lineation (Lst), plunges $0^{\circ}$ to $15^{\circ}$ to the north (Fig. 4d). A schistosity foliation plane (Ss) and a shear band foliation plane $\left(\mathrm{Sc}^{\prime}\right)$ are also observed. The first one strikes $32^{\circ}$ to north-east and dips $64^{\circ}$ to north-west (Fig. 3d), yielding a mean angle about $20^{\circ}$ between S-C surfaces, and the Sc' trends $27^{\circ}$ to north-west, and dips $61^{\circ} \mathrm{SW}$ (Fig. $4 d)$.

The most conspicuous structure around the central and southern portions of Antas III deposit ( $\mathrm{K}$ and $\mathrm{P}$ orebodies respectively) is the mylonitic foliation $(\mathrm{Sm})$ which strikes $\mathrm{N} 27^{\circ} \mathrm{E} / 48^{\circ} \mathrm{NW}$ at $\mathrm{K}$ Orebody (Fig. 4e) and $\mathrm{N} 02^{\circ} \mathrm{E} / 54^{\circ} \mathrm{NW}$ at $\mathrm{P}$ Orebody. The trend of mylonitic foliation in $\mathrm{K}$ Orebody is rotated $26^{\circ}$ to the north-east from the $\mathrm{Sm}$ of $\mathrm{H}-$ and P-Orebody; this deflection in strike is probably the result of movement along late ENE-WSW faults (Fig. 2). The stretching lineation of K Orebody have steeper plunges and different orientation than both $\mathrm{H}$ and $\mathrm{P}$ orebodies $\left(\mathrm{N} 21^{\circ} \mathrm{W} / 35^{\circ}\right.$ - Fig. 3e).
The M Orebody is situated east of the zone defined as SZ-I, which contains the $\mathrm{H}, \mathrm{K}$, and $\mathrm{P}$ orebodies (Fig. 2). However, the surface mapping indicated that the zone between the so-called SZ-I and the M-Orebody is also strongly foliated, what may signify that the SZ-I is wider at this location. The observed structures in M-Orebody are similar to those observed in $\mathrm{H}$ Orebody. The Sm foliation strikes $\mathrm{N} 02^{\circ} \mathrm{F} 754^{\circ} \mathrm{W}$ (Fig. 3f), and the stretching lineations have plunges $28^{\circ} \mathrm{N}$ to NS (Fig. 4f). The Ss and $\mathrm{Sc}^{\prime}$ foliations $\left(\mathrm{N} 27^{\circ} \mathrm{E} / 73^{\circ} \mathrm{NW}\right.$ and $\mathrm{N} 12^{\circ} \mathrm{W} / 67^{\circ} \mathrm{SW}$ respectively) are also well preserved (Fig. $4 \mathrm{f}$ ). The angle between the $\mathrm{Sm}$ and $\mathrm{Ss}$ foliations is $26^{\circ}$, either indicating a smaller intensity of deformation or more probably, a different response to the difference in rocks competence.

Structural Characterization of Shear Zone-II (SZ-II) The structural characterization of SZ-II was based on det alled observations in the outcrops along the margin of the Itapicuru river (station $n^{\circ} 2$ in figure 2) and in the open pits of several orebodies from Antas II Deposit, which will be treated collectively.

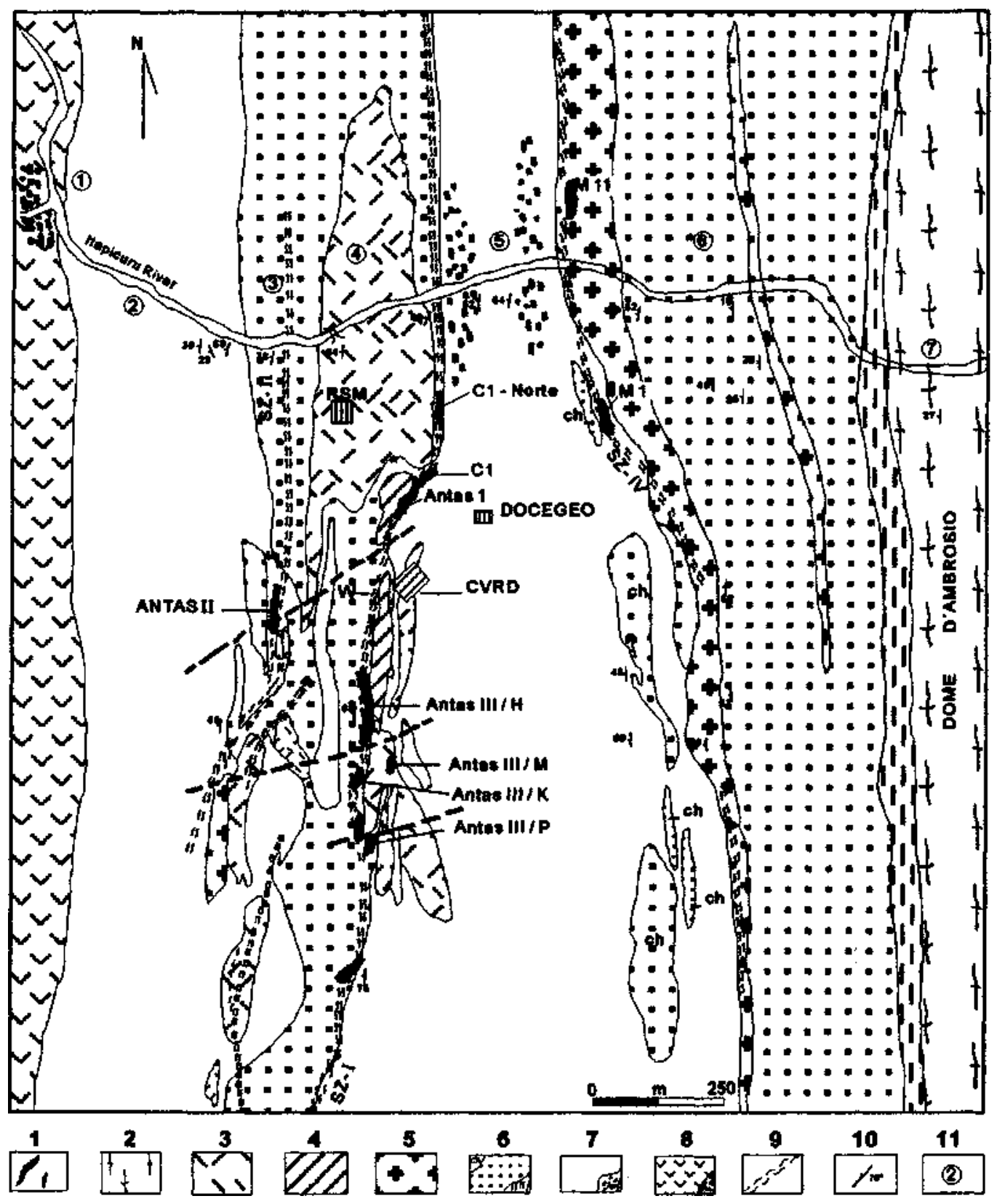

Figure 2 - Regional geologic map ofFazenda Maria Preta Gold District: 1 =orebodies; 2 = granitic dome (Ambrósio dome); $3=$ meta-diorite; $4=$ meta-dacite; 5 = meta-gabbro; $6=$ undifferentiated meta-sediment/meta-chert; 7 = banded iron formation; $8=$ meta-andesite; $9=$ meta-basalts; 10 = lapilli and bomb-sized fragments; $11=$ shear zones; $12=$ stop of the Itapicuru geological section. After DOCEGEO, Internal Report (Unpublished). 
The internal structure of Antas II deposit is characterized by a complex structural pattern resulting from superimposed structures. It can be divided as a whole in two relatively homogeneous domains, Antas II-North (R, K and I orebodies) and Antas II-South (H, E and U orebodies), as previously proposed by Alves da Silva \& Matos (1991).

In both domains, the mylonitic foliation defining the shear zone trends dominantly $02^{\circ}$ to north-east and dips $65^{\circ}$ to north-west, but present different dispersion pole patterns of the mylonitic foliation (Figs. 5a and 5b); in Antas II-North this dispersion is dominantly to the north whereas in Antas II-South it is to the south. In the northern domain, the mineral and stretching lineations dip predominantly to south, whereas in the southern domain, they plunge predominantly to the north-west (Figs. 5a and 5b).

Significant folding of well preserved sedimentary bedding and mylonitic foliation is represented by $F$ ] synschistose and $F_{2}$ chevrontype late folds. F, synschistose folds show variable axial planes (mostly sub-vertical) and N-S trending subhorizontal axes. A composite stretching and crenulation lineation is developed parallel to the $\mathrm{F} \mid$ fold axes (Fig. 5c) (Coelho et al. 1990, 1991).

The well preserved sedimentary bedding $\left(\mathrm{S}_{0}\right)$, in sericitic schists from station $n^{\circ} 2$ along the margins of the Itapicuru river and from outcrops of $\mathrm{Cl}-\mathrm{W}$ prospect, which are situated to north of Antas II deposit (Fig. 2), exhibits tight to open kink and chevron folds, which develop a discrete spaced axial plane cleavage which trends $\mathrm{N} 45^{\circ} \mathrm{E} / 61^{\circ} \mathrm{NW}$ (Fig. 5d); the axes of these folds, named $\mathrm{F}_{2 \mathrm{a}}$, show double dip and maxima concentrated around $38 / \mathrm{S} 54^{\circ} \mathrm{W}$ (Fig. 5d); the intersection of this cleavage with the sedimentary bedding defines a lineation parallel to the fold axes. The dispersion of the $S_{0}$ defines a $\pi$ plane whose constructed axes dips $41^{\circ}$ to N05 ${ }^{\circ} \mathrm{E}$ (Fig. 5e).

Structural Characterization of Shear Zone-IV (SZ-IV) The structural data of SZ-IV was based on det alled observations in the

open pits of M-1 and M-1 1 deposits in the south and in Man Deposit, in the northern extremity of the shear zone.

M-1 AND M-11 DEPOSITS The structural data of these deposits will be presented together. In the meta-sedimentary rocks of M-11 mine, the sedimentary bedding $\left(\mathrm{S}_{0}\right)$ is still preserved and folded up, with the axial planes parallel to the $\mathrm{Sm}\left(\mathrm{F}_{1}\right.$ folds), which strikes $13^{\circ}$ north-east and dips $55^{\circ}$ to north-west. Fold axes $\left(\mathrm{L}_{1}\right)$ are parallel to the intersection lineations $\left(\mathrm{Li}_{1}\right)$, which are also parallel to the stretching lineation, dipping at about $30^{\circ}$ to south (Fig. 5f). The M-l quartz vein, emplaced along the mylonitic foliation $\left(\mathrm{Nl} 1^{\circ} \mathrm{E} / 66^{\circ} \mathrm{NW}\right)$, show its long axes parallel to the sub-horizontal stretching lineation, which in this case plunges slight to the north (Fig. 5f). An elongation lineation defined by the shape of fragments in the host conglomerate plunges at about $70^{\circ} \mathrm{SW}$ (Robert 1992).

MARI DEPOSIT Preliminary structural data in $\mathrm{C} 1 \mathrm{~A}$ and $\mathrm{C} 2 / \mathrm{C} 3$ open-pits show that the most conspicuous structure is the mylonitic foliation. In the $\mathrm{C} 1 \mathrm{~A}$ orebody it trends $38^{\circ}$ north-east and dips $55^{\circ}$ to north-west, while in the $\mathrm{C} 2$ Orebody the $\mathrm{Sm}$ is oriented $\mathrm{N} 20^{\circ} \mathrm{E} / 71^{\circ} \mathrm{NW}$. The relationship between the mylonitic foliations at these two localities is not yet well undersood. They could represent the Sm foliation with different orientation due to a refraction in the more competent gabbroic body.

STRUCTURAL CHARACTERISTICS OF GOLD-QUARTZ VEINS As cited above (see Table 1), most mineralized zones in FMP gold district consist of gold quartz veins and associated altered and veined wallrocks. This section examines in det all the structural setting of the veins, their types, their orientations and geometries, and their relationships to the deformation processes under which they formed.

Almost all mineralized veins in FMP gold district are emplaced within shear zones, and in a general way, they may be divided in two types, according to Poulsen \& Robert (1989), Robert (1990) and Robert \& Poulsen (1994): shear veins and extensional veins. Breccia veins are also relatively common in the FMP gold district. Fracturefilling vein (Colvine et al. 1988) is represented by the Antas I/C1 quartz veins. In the more competent rocks (meta-dacites and meta-diorites) centimetric and discontinuous quartz veins (stockwork) are relatively common, and will also be discussed below. Most quartz veins have relatively simple geometries, consisting of single sets of shear veins. However, more complex sets of veins are locally also present.

Shear Veins Shear veins are by far the most common type in the FMP gold district. They are found in all deposits and are parallel or sub-parallel to the mylonitic foliation, i.e., they strike $\mathrm{N} 13^{\circ} \mathrm{E}$ and dip $55^{\circ} \mathrm{NW}$ (Fig. 3b) They are generally decimetric to metric in thickness and metric to decametric in length.

C1 -NORTH DEPOSIT Two types of shear veins are observed in this deposit according to the host rock: (i) the veins emplaced in metasediments and along the contact metasediments/meta-diorite are massive, metric in length and centimetric to metric in thickness, (ii) in the sheared meta-diorite, they form a swarm of centimetric and discontinuous parallel quartz veins. The average veins orientation is $\mathrm{N} 10^{\circ} \mathrm{W} / 55^{\circ} \mathrm{SW}$, which is exactly coincident with the average trend of the mylonitic foliation (Sm).

ANTAS III DEPOSIT The shear veins in Antas III deposit are the major vein type and are observed in all orebodies of this deposit, which show the same average orientation of mylonitic foliations (Sm), i.e., $\mathrm{N} 02^{\circ} \mathrm{E} / 54^{\circ} \mathrm{NW}$. In $\mathrm{H}$ Orebody they totalize about $40 \%$ of the ore and are texturally divided into two types: (i) "breccia" veins, which are the most widespread; and (ii) "massive" quartz veins. In K, M, and P orebodies the mineralization is essentially composed of "massive" quartz veins (Fig. 6).

ANTAS II DEPOSIT The mineralized quartz veins of Antas II deposit are dominantly constituted by quartz and carbonate. They are essentially massive veins, but some may contain fragments in their borders (ribbon veins). Generally the veins present a relatively simple geometry, i.e., parallel to the mylonitic foliation, but folded veins are also relatively common in the Antas II-R Orebody, where kink and chevron late folds, responsible for the folding of the veins, are concentrated (Fig. 7). Among the orebodies which comprise the northern domain of Antas II deposit, the K and I orebodies are dominantly composed by shear veins which are oriented parallel to the mylonitic foliation.

In the southern domain of Antas II the quartz-carbonate veins are mainly hosted along the mylonitic foliation, which presents a general trend of $\mathrm{N} 02^{\circ} \mathrm{E} / 65^{\circ} \mathrm{NW}$. In the E Orebody, there are two dominant sets of quartz veins oriented NS and EW respectively (Fig. 8). The NS set,

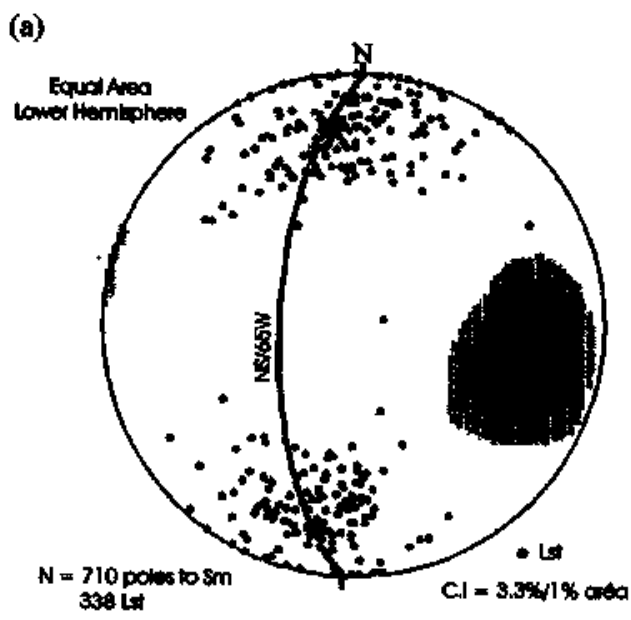

(b)

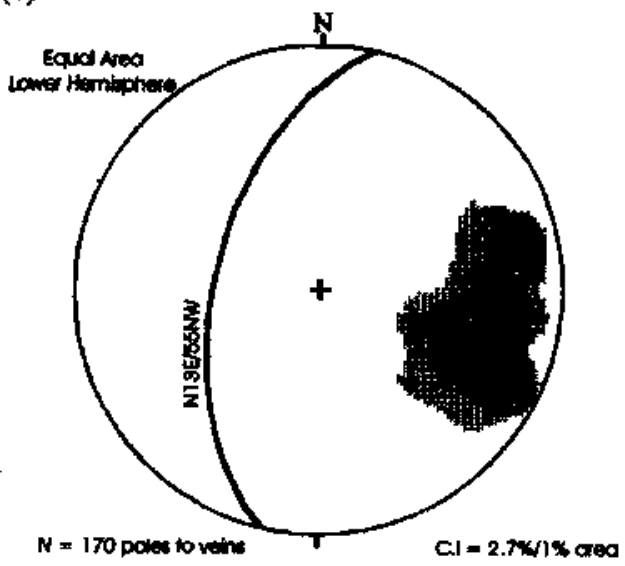

Figure 3 - Fazenda Maria Preta district (a): structural data; (b) vein data 
Table 1 - Main characteristics of each deposit from Fazenda Maria Preta gold district.

\begin{tabular}{|c|c|c|c|}
\hline 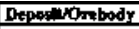 & TStar Zage & Stant Rodk & 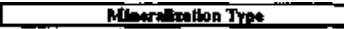 \\
\hline Amas I & szal & dache & 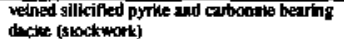 \\
\hline $\begin{array}{l}\text { Amat I } \\
\text { CI } \\
\text { CINGorh } \\
\text { W }\end{array}$ & $\begin{array}{l}s 21 \\
s 21 \\
\text { s2-1 } \\
\text { S2-1 }\end{array}$ & 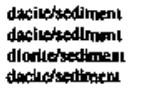 & 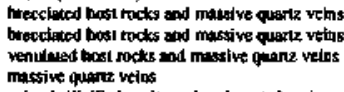 \\
\hline Anux IIV/H & szi & decile & 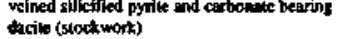 \\
\hline 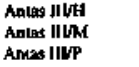 & $\begin{array}{l}\text { SL-1 } \\
\text { SZ-1 } \\
\text { sL-1 }\end{array}$ & 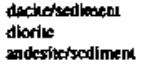 & 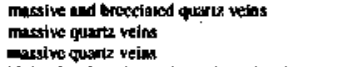 \\
\hline Antis IIR & $52-11$ & secinkal & 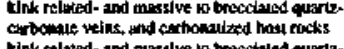 \\
\hline Anose IUK & $52-\Pi$ & secimpal & 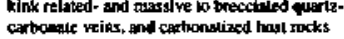 \\
\hline Anlas IUI & sz-II & andesichisedilnent & 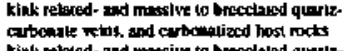 \\
\hline Antas lly: & $\$ 2-11$ & manderidebsol iment & 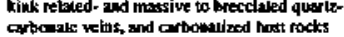 \\
\hline 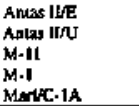 & 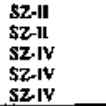 & 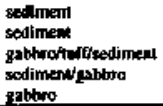 & 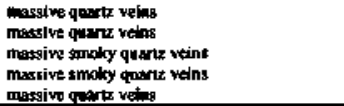 \\
\hline
\end{tabular}

which is parallel to $\mathrm{Sm}$, is made up by two main quartz veins; the biggest one presents a great thickness but only its margins and the wall-rocks are mineralized, whereas in the smaller one, which presents a general trend of $\mathrm{N} 73^{\circ} \mathrm{W} / 79^{\circ} \mathrm{SW}$, the mineralization occurs throughout the vein. In the U Orebody some quartz veins are also hosted along the mylonitic foliation.

M-1 AND M-11 DEPOSITS In the M-11 deposit the mineralization comprises two quartz veins sets (Fig. 9). The main set is comprised by two parallel veins, as revealed det alled mapping in the pit (Robert 1992). The one situated in the eastern part of the open pit is hosted along the axial planes of the F, folds, which in turns are parallel to the mylonitic foliation, which trends $13^{\circ}$ north-east and dips $55^{\circ}$ to northwest. To the north of the open pit, the attitute of the lithologic contacts and the foliation indicate the existence of a fold. According to Robert (1992), the geometry of this fold and the repetition of the crystal tuff unit and the two parallel sets of veins in the western part of the deposit suggest that the fold is a "drag fold" related to a discontinuity oriented roughly NS (Fig. 9).

MAPI DEPOSIT The quartz veins in the CIA orebody are massive veins, hosted along the mylonitic foliation of the sheared zones in the meta gabbroic rocks, characterizing, thus typical shear veins.

Extensional Veins According to Poulsen \& Robert (1990) and Robert \& Poulsen (1994) two types of extensional veins can be distinguished based on their distribution relative to the shear zones: (i) internal to shear zones, generally thin small and barren veins, commonly displaying sigmoidal shapes; and (ii) external to shear zones, generally with shallow dips ("flat veins"), extending outside the shear zones in less strained rocks for distances up to several tens of meters, ranging from centimetric to metric in thickness.

Neither internal nor external extensional veins are abundant in the FMP gold district. Extension veins internal to the shear zone are characteristically small thin veins (generally less than one meter long and less than $10 \mathrm{~cm}$ thick), perpendicular to foliation, with shallow dips; they are observed in the H Orebody of Antas III deposit, Ml deposit, and in E Orebody of Antas II deposit. Extensional veins external to the shear zone are observed in W Orebody of SZ-I and E-Orebody of Antas H-South deposit; however, they show a remarkable difference in attitute: whereas the vein in W orebody is a NS typical shallow dip vein ("flat vein" - Fig. 10), the one of the Antas II-E Orebody is EW and have sub-vertical dip.

Breccia Veins Breccia veins are spatially associated with competent lithologies, such as the dacitic rocks in the Antas III-H Orebody. As cited before, the fragments are angular-shaped and immersed in a quartz matrix. The fragments are themselves altered and cut by veinlets (stockwork). Our observations suggest that these are hydraulic breccias formed in an environment where fluid pressure was important. The difference in competence between the dacitic and the tuffaceous rocks in the $\mathrm{H}$ Orebody area may have maintained impermeable zones and may caused local high fluid pressures, which in turn created the hydraulic breccias in the dacite.

Fracture-Filling Vein A marked structural feature observed in Antas I and $\mathrm{Cl}$ open pits is a $46^{\circ} \mathrm{E}$ trending structure dipping $46^{\circ}$ to north-west, located in the footwall of the orebodies, which can be followed for approximately $700 \mathrm{~m}$ along strike.

The quartz veins emplaced along this zone (Fig. 11) are centimetric to hundreds of meters long with variable width, and show a massive to brecciated aspect. In thin sections, the quartz grains show deformation features like ondulous extinction, development of sub-grains, and pervasive recrystallization, not observed in the others quartz veins, which demonstrate that they were sheared after their emplacement.

Indeed, surface mapping on the dacitic body show several narrow zones oriented NS containing intensely foliated rocks (as the schistified aspect of the dacitic rocks of Antas III deposit), cross-cutting the $\mathrm{N} 46^{\circ} \mathrm{E}$ structure (Coelho et al. 1990, 1991), what indicates that this structure does not represents the large scale anastomosed pattern of the SZ-I, but a previous structure in relation to the shearing event. Steep-dipping striations in the fault mirrors indicate a normal fault, what is compatible with the dragging of the mylonitic foliation next to this fault. The abundant fault breccias and fractured rocks clearly indicate late reactivation of this fault, what may result in truncation and offset of the orebodies.

Stockwork Networks of quartz(-siderite) veins in weakly to nonfoliated hydrothermally altered (silicification, pyritisation, albitisation) dacite characterize the stockwork. The veinlets that compose this stockwork have irregular walls recovered by siderite crystals, with quartz occupying the central portions. They are small, up to few centimeters long, and less than $1 \mathrm{~cm}$ thick. In some foliated zones within the dacitic body they are parallel to the mylonitic foliation, indicating that they are clearly overprinted by the shearing event. Thus, they represent an early-stage mineralizing event, possibly related to magmatic activity. Fragments of this type of ore are commonly recognized in some "breccia" veins, which confirm that they pre-dated, at least, part of the veining event in the Fazenda Maria Preta area.

Similar quartz(-siderite) veins showing planar and regular walls and up to a few meters long and few centimeters thick are observed in non-foliated dioritic rocks, in $\mathrm{Cl}$ deposit. Hydrothermal alteration is absent in the host diorite and the veins are not mineralized (A.S.B. Scares, Oral Communication), which don't characterize them as stockwork vein type.

KINEMATICS AND STRAIN ANALYSIS OF THE FMP DEFORMATION ZONE In general, clear direct evidences of the direction or sense of shear were not observed in the FMP Deformation zone. Few evidences for Antas III, Antas II and M-1 deposits suggest reverse and strike slip movements, as discussed below.

In the $\mathrm{H}$ and $\mathrm{M}$ orebodies of Antas III deposit, the intersection between "C and S" planes (B-axes) plunges consistently at high angle to the elongation lineation. The plunge of the elongation lineation is shallow-north and thus indicates a strike-slip movement along SZ-I. The arrangement between "C and S" planes indicates a sinistral horizontal component of movement. Furthermore, the presence of EW vertical extensional vein at Antas II-E Orebody suggest also strike slip movement in SZ-II.

On the contrary, in M-1 deposit, the presence of elongation lineation of the clasts in the host conglomerate plunging moderately to southwest, coupled with shallow-dipping extensional veins, indicate oblique, reverse-dextral slip (Robert 1992). As further examined above, the presence of shallowly extensional veins external to shear zone ("flat veins") at W deposit as well as locally preserved down-dip stretching lineations in Antas III-H Orebody suggest early reverse movements in portions of the SZ-I.

Strain Analysis According to Ramsay \& Graham (1970) and Ramsay (1980), the XY plane of the ellipsoid corresponds to the Ss foliation within the shear zone and the Z-axes is perpendicular to this plane. In the case of the FMP deformation zone rare "C and S" fabrics, prevent a more accurate strain analysis. As showed above, reliable "C and S" fabrics are only present in the Antas III-H and M orebodies. Thus, in order to determine the orientation of the finite strain ellipsoid we used the average of the orientations of the mylonitic foliation (Sm) and the schistosity foliation (Ss) measured within these orebodies. The Y-axes of the strain ellipsoid was deduced from the mylonitic and schistosity foliations intersection, resulting an axes plunging $53^{\circ}$ to $\mathrm{S} 40^{\circ} \mathrm{W}$. As the measured stretching lineations (Lst) in this study can not be used in order to determine the X-axes, because they lie in the Sm plane instead of Ss plane, the X-axes $\left(25^{\circ} / \mathrm{N} 10^{\circ} \mathrm{E}\right)$ was obtained from $90^{\circ}$ of the Y-axes, along the Ss-plane. The Z-axes is the own pole to the Ss plane $\left(307 \mathrm{~S} 60^{\circ} \mathrm{E}\right)$ (Fig. 12). The angle between the Z-axes and $\mathrm{C}$ plane $(\mathrm{Sm})$ is about $30^{\circ}$, which is the angle normally found in 

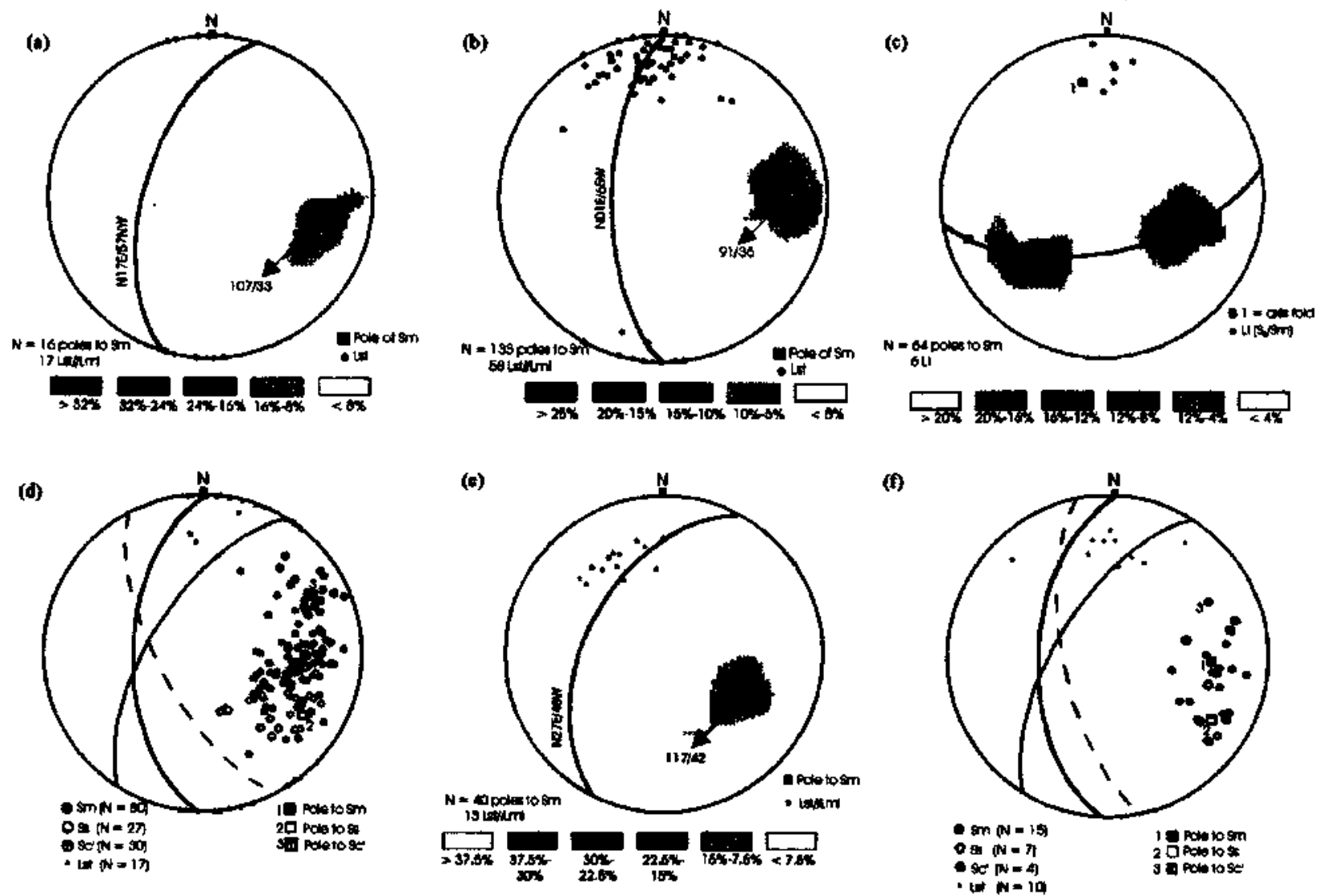

Figure 4-1\% area contour stereogram constructions of structural data: (a) contoured poles to Sm and poles to Lst in volcanic meta-agglomerates; (b)contoured poles to Smfrom Antas I, Cl and Cl-Norte mines; (c) contoured poles to Sø and cylindrical fold axes from Cl mine; (d) poles to Sm, Ss, Sc', Lst and relationship among the representative planes to Sm, Ss and Sc' foliations from Antas III-H Orebody; (e) contoured poles to Sm and poles to Lst from Antas III-K Orebody; and (f) poles to Sm, Ss, Sc', Lst and the relationship among the representative planes to Sm, Ss and Sc' foliations from Antas III-M Orebody. See text for discussion.

the results of experimental shear of rocks (Borg \& Handin 1966, Hobbs et al. 7976). This angle indicates little re-orientation of the Ss foliation in direction of the Sm foliation. If we rotate the Z-axes to its theoretical position of $45^{\circ}$ (without considering the internal friction and cohesion) in relation to C-plane, the obtained S-plane would be $\mathrm{N} 45^{\circ} \mathrm{E} / 68^{\circ} \mathrm{NW}$. An aproximation of the finite strain of the area was presented by Davison et al. (1988) applying the X/Z ratios of pyroclastic fragments, pillow lavas and other markers observed in the Itapicuru river section, where the flattenning is considered to be a maximum value for tectonic deformation; these authors obtained low to moderate values of the deformation (2.1 to 12.0) and an oblate finite strain fabric with $\mathrm{X}$ approximately equal to $\mathrm{Y}$. The best outcrops outside the Itapicuru river section for such a quantification occur in the Antas III-H Orebody; it consists of boudinaged intercalations of black meta-cherts in metasediments, where the $\mathrm{X} / \mathrm{Z}$ and $\mathrm{Y} / \mathrm{Z}$ ratios give a mean value of 9.94 and 8.40 respectively, in agreement with the values obtained by Davison et al. (1988). The finite strain fabric is also oblate, but the flattening along the $\mathrm{X}$-axes is a little larger than along the $\mathrm{Y}$-axes $(\mathrm{X} / \mathrm{Y}$ ratio = 1.18). These obtained values explain the small re-orientation of Ssplane in the direction of the Sm-plane.

MODEL FOR THE EMPLACEMENT OF THE VEIN SYSTEMS Any model for emplacement of the vein system in FMP district must take into account the following points :

1. In a general point of view, the mineralized veins are hosted along dominantly sinistral strike-slip shear zones (SZ-I, SZ-II, SZ-III and SZ-IV - see Fig. 2). The compatibility of the quartz vein systems with the structural elements recorded in the shear zones, indicates that both, veins and shear zones, were formed or emplaced during the same progressive deformation event;

2. The shear zones of the FMP district are considered as second order shear zones, parallel to the first order shear zone, the Main Shear Zone;
3. The field relations and the internal deformation features of the veins indicate that they were formed or hosted in different stages during theDl deformation event.

4. The anisotropy between the more competent rocks (dacites, diorites and gabbros) and the less competent ones (volcanics, tuffs and sediments) played an important role in the development of the shear zones and location of the orebodies, which mainly developed along the rocks contacts;

5. The mineralized veins are mainly of shear-vein type. Some extensional veins, related to reverse movement in the shear zones, are also present;

6. In almost all veins the filling is usually massive, with little evidence of free crystal growth. Some veins incorporated wall-rock fragments ("breccia veins").

The fact that the SZ-I to SZ-IV are second order shear zones, parallel to the first order MSZ, besides the fact that they are strike-slip faults, signifies reduced open spaces to accomodate the mineralization. In this case, dilation depends on tectonic forces operating in a high fluid pressure environment (Hodgson 1989a and b). The main deformation mechanism which cause dilatancy could be the movement on non-planar shear surfaces, developed along the contact between the more competent and the less competent rocks. The difference in competence may have maintained impermeable zones which caused local high fluid pressures. The association of these two facts may have been responsible for the opening of the fractures.

Based on the geometrical relationships of the vein types and on the preceding structural analysis of the area, a two stage model is preliminary proposed for the formation and emplacement of the shear veins in FMP district:

Stage 1 - Initial dilatancy caused by movement along the irregular contact between lithologies with competency contrast, increased by fluid overpressuring. The brittle failure occurs when there is an in- 
(a)

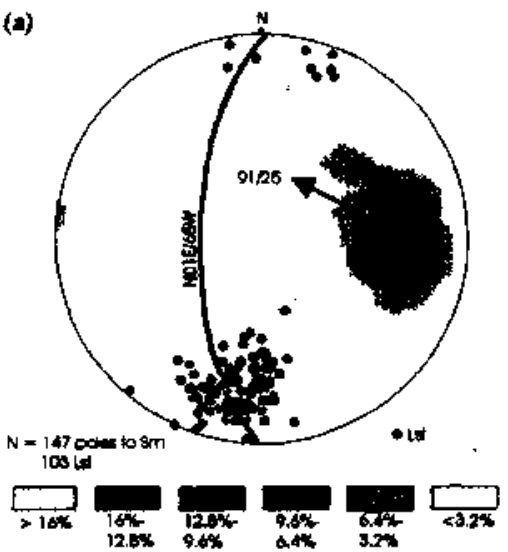

(d)

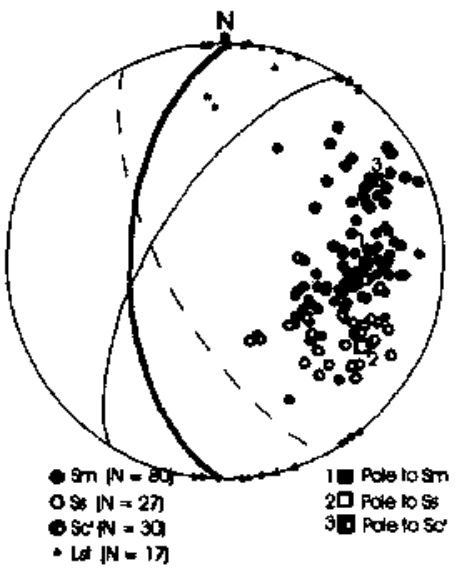

(b)

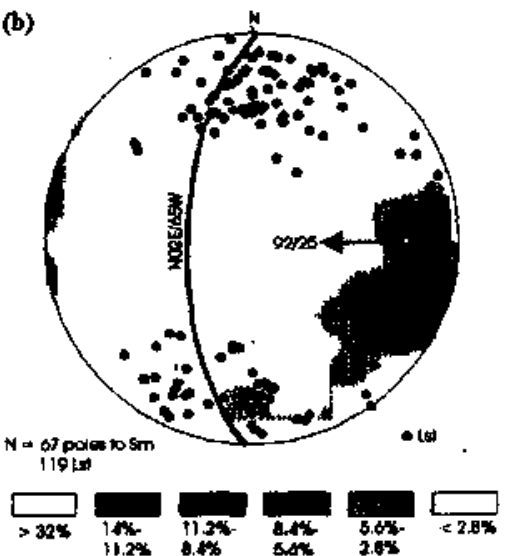

(e)

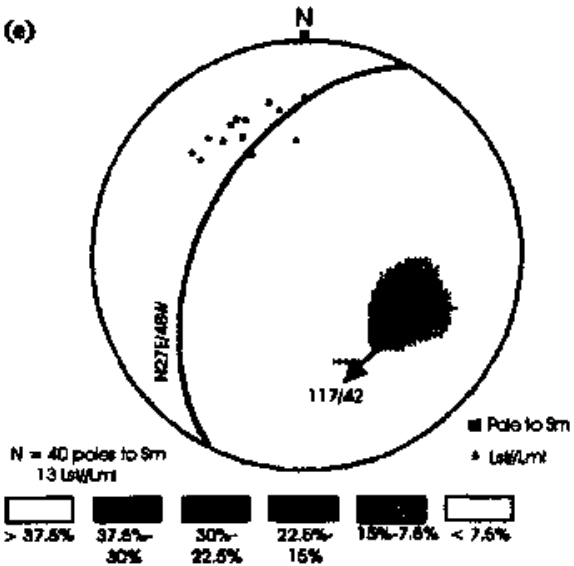

(c)

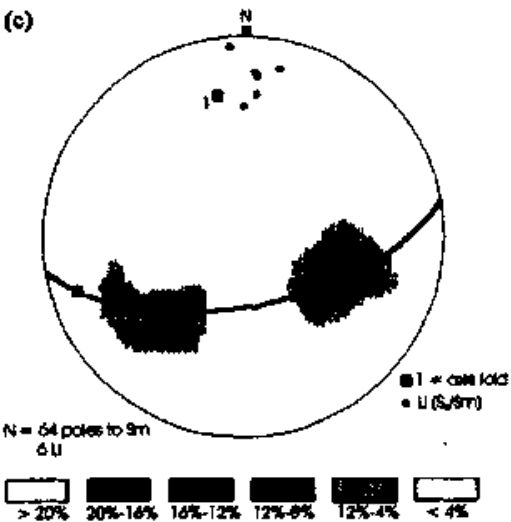

(F)

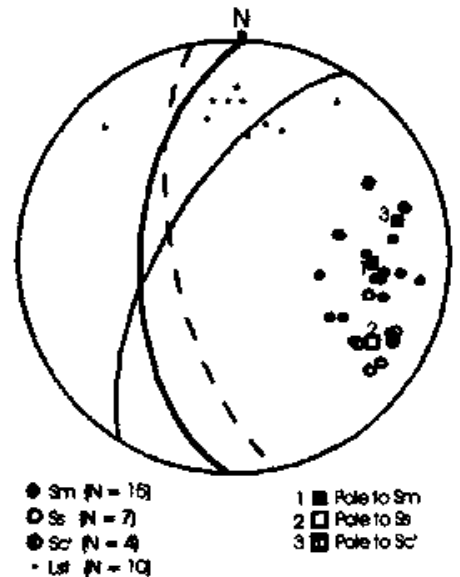

Figure 5 - $1 \%$ area contour stereogram constructions of structural data: (a) contoured poles to Sm and poles to Lst and Lmi (Lst/Lmi) from Antas II northern domain; (b contoured poles to Sm and poles to Lst and Lmi (Lst//Lmi)from Antas II southern domain; (c) contoured poles to API and poles to Lcl and Lmi (Lst//Lmi)from Antas II deposit; (d) contoured poles to AP2 and poles to folding axes from Antas II deposit; (e) contoured poles to Sø and constructed cylindrical fold axes ( $\beta 3)$ from $C 1-W$ Target and outcrop $n^{\circ} 2$ of the Itapicuru river section; (f) contoured poles to Sm and poles to Lst from Ml and Ml 1 mines. See text for discussion.

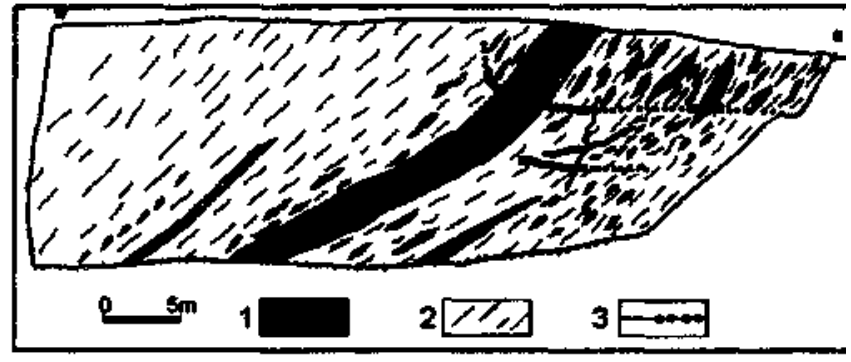

Figure 6 - Cross section of the K orebodyfrom Antas III mine (section SK-07): 1 = quartz veins; 2 = sheared meta-sediments; 3 = economic mineralization/sub-economic mineralization. After CVRD Internal Rapport (Unpublished).

crease of fluid pressure (Pfluid $\geq \sigma_{3}+\mathrm{T}$ ). As in FMP district dilatancy occurred both in shear and extensional fractures, this indicate that the fluid pressure exceeded even locally, the maximum principal confining stress (Pfluid $\geq \sigma_{1}+\mathrm{T}$ ).

The performance of the fluid pressure in the formation of the shear veins is depicted from the fluid inclusion and isotopic studies. The pressure of the emplacement of the veins, deduced from the fluid inclusion study is around $2 \mathrm{~Kb}$ (Xavier 1991, Coelho 1994). Based on isotopic data, Xavier (1991) concluded that the mineralizing fluids are of metamorphic origin. As the pressure data of regional metamorphism range from 2 up to $4 \mathrm{~Kb}$ (Silva 1984, 1987), it seems clear that there

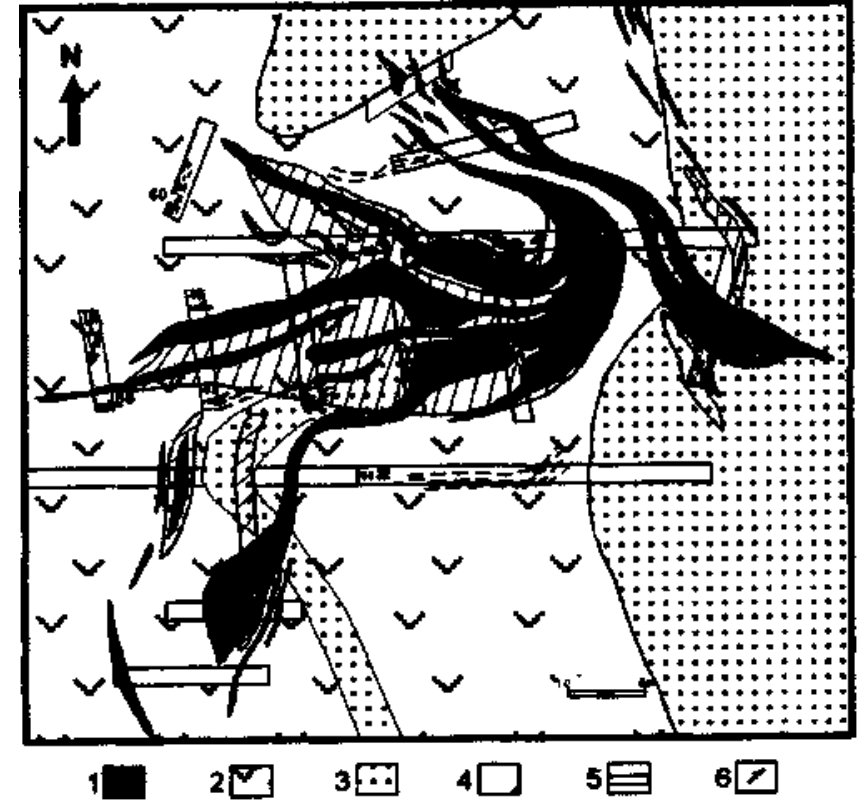

Figure 7 - Geologic map of R orebodyfrom Antas II-North sector: 1 = quartz veins; $2=$ meta-andesites; $3=$ meta-sediments; $4=$ mineralized zone; 5 = trench; $6=$ foliation. After DOCEGEO Internal Rapport (Unpublished). 


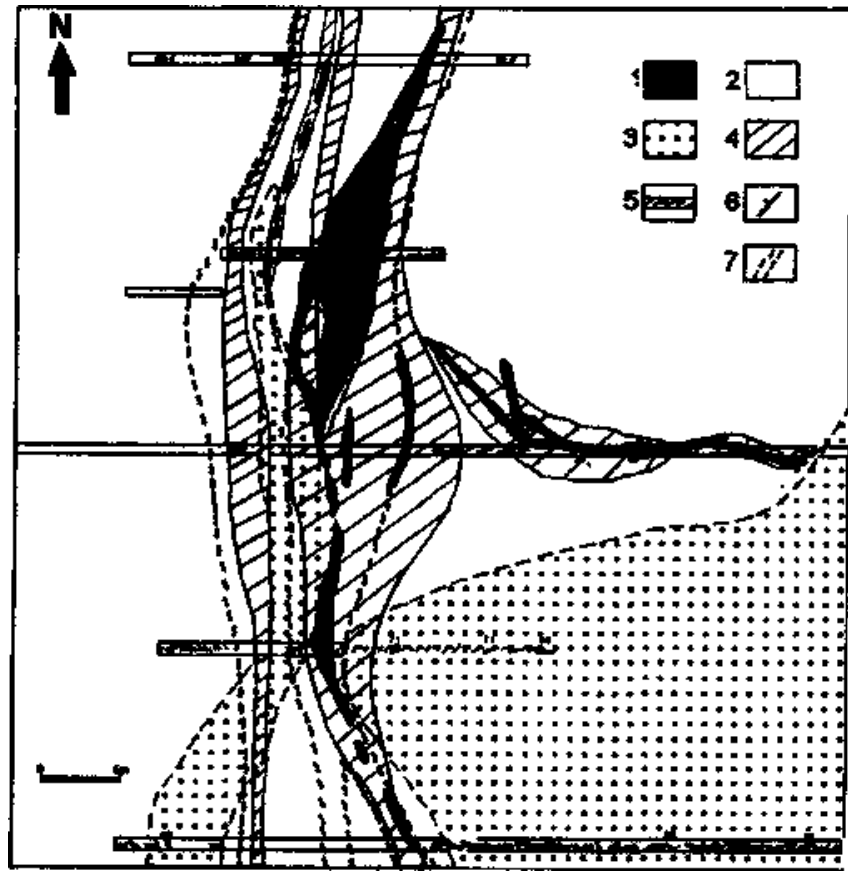

Figure 8 - Geologic map of E orebody from AnuisII-Souili sector: 1 = quartz veins; 2 = meta-andesites; $3=$ meta-sediments; $4=$ mineralized zone; 5 = trench; $6=$ foliation; $7=$ shear zone limit. After DOCEGEO Internal Rapport (Unpublished).

was a pressure gradient from the regional terranes to the neighboring shear zones; this mechanism is analogous to a pressure bomb, with the fluids migrating from the high pressure to the low pressure zones. This stage corresponds to the failure stage of the fault-valve model of Sibson et al. (1988).

Stage 2 - Discharge of the fluids through the shear fractures promotes a drop in fluid pressure. When the shear fractures are sealed, the fluid pressure and the shear stress build up again, as predicted by the fault-valve model (Sibson et al. 7988).

Typical textures of open space filling are rare or absent in most quartz veins of FMP district, what suggest that the fracture walls were abruptly jacked apart by a great discharge of fluids followed by a rapid precipitation of silica. This rapid precipitation of silica is related to a volatilization process of carbonaceous matter in the host rocks to $\mathrm{CO}_{2}$ (Coelho \& Ramboz, 1998); gangue quartz precipitated in response to the abrupt dilution of 'normal' aqueous metamorphic fluids by the organic-derived $\mathrm{CO}_{2}$.

\section{STRUCTURAL CONTROL FOR THE QUARTZ VEINS The} plunge of kinematic ore shoots, i.e., those related to vein formation in active shear zones, generally varies from perpendicular to parallel in relation to the slip direction along the shear zone (Poulsen \& Robert 1989, Robert \& Poulsen 1994).

In the case of FMP district, Alves da Silva \& Matos (1991) and Scares et al. (1992) indicate that the orebodies are controlled mainly by a stretching lineation plunging $20^{\circ}-30^{\circ}$ to north.

In our study, according with the structural analysis, the oreshoots are mostly located along transcurrent sinistral slip faults, hosted in shear fractures. The oreshoots show a tabular form, concordant with the structures where they are hosted, reflecting the main control of the mineralization. As it was showed above, the measured stretching lineations (Lst) in this study do not correspond to a X lineation (Lx), since they lie in the Sm plane instead of Ss plane. However, they constitute a secondary control of the mineralization, since all the orebodies can be reoriented along them, with the progression of the deformation. This fact is well characterized by the common occurrence of boudinaged veins. However, the reorientation due to the stretching was not so strong, as indicated by the angle between $\mathrm{S}-\mathrm{C}$ foliations (next to $30^{\circ}$ - see Figs, 11 a and b, 15d and 16b); thus, the primary tabular control is still the main control of the oreshoots, although overprinting late brittle deformation (faulting) can easily modify the original geometry of the orebodies.

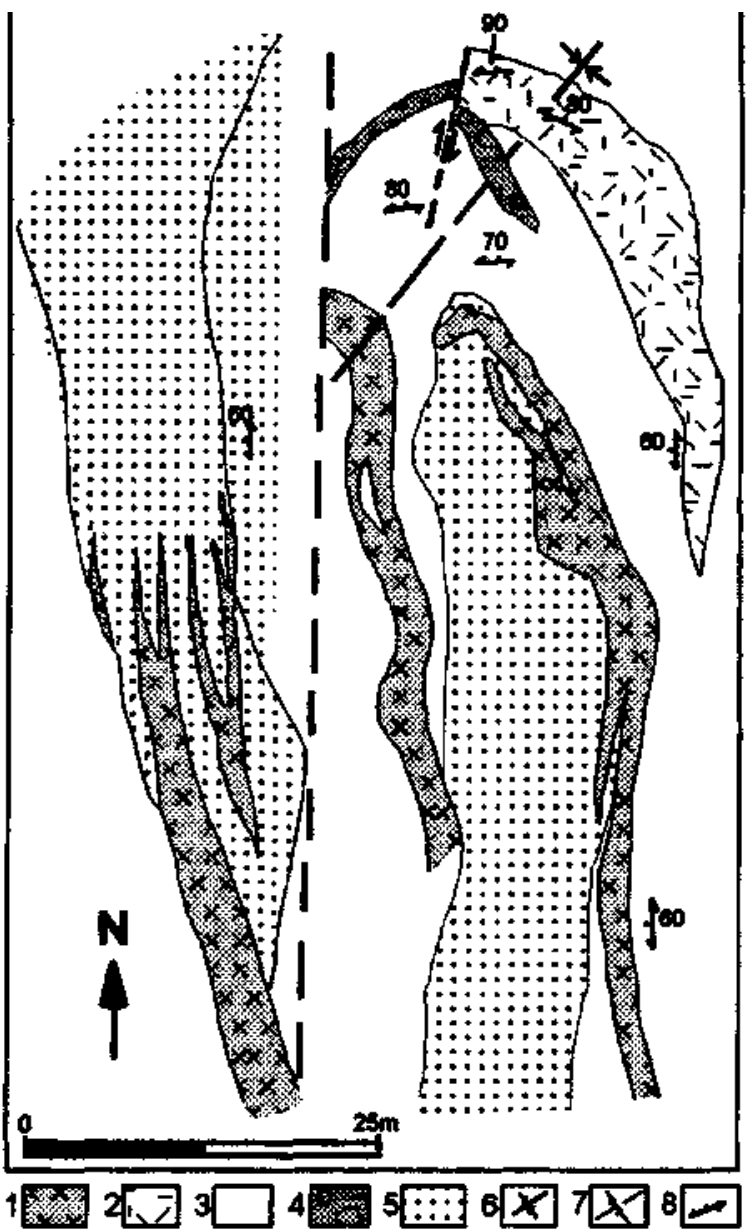

Figure 9 - Geologic map of the pit's $M$-ll deposit: 1 = quartz veins; 2 = meta-gabbro; 3 = meta-phyllite; 4 = meta-conglomerat; $5=$ meta-tuff; $6=$ fold axis; $7=$ strike-slip fault; $8=$ foliation. Simplified from Robert (1992).

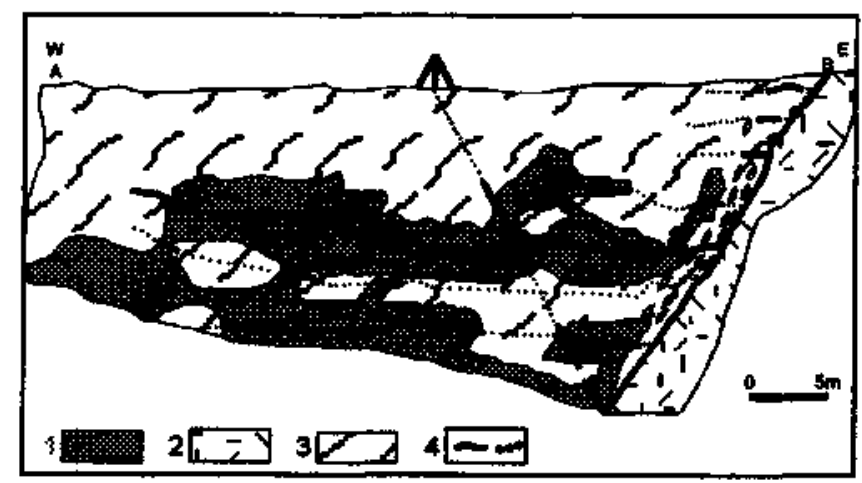

Figure 10 - Cross section of the $W$ orebody (section $S W-18$ ): 1 = quartz veins; 2 = meta-dacites; 3 = meta-sediments; 4 = economic mineralization/sub-economic mineralization. After CVRD Internal Rapport (Unpublished).

SUMMARY AND CONCLUSIONS The major conclusions of this study are as follows.

1. According to our structural study, the deformation in the FMP district is characterized by a well marked NS foliation dipping about $60^{\circ} \mathrm{W}$, with shallowly-plunging stretching lineation predominantly to the north. The zones where this foliation is more intensely developed were characterized as shear zones (SZ-I to IV). In these zones, the main structural elements observed were mylonitic foliations, stretching lineations, shear and tension fractures, and veins. These elements 


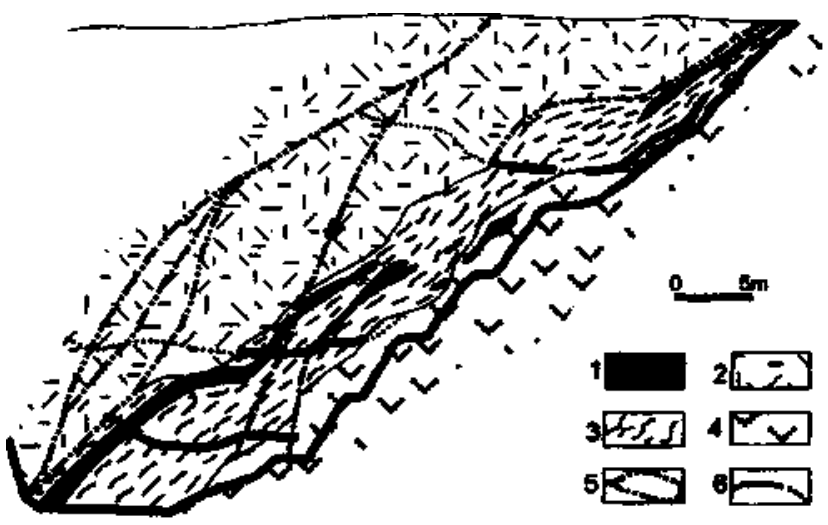

Figure 11 - Cross section of the Antas 11 mine (section SA-18): $1=$ quartz veins; 2 = meta-dacites; 3 = meta-sediments; $4=$ meta-andesites; 5 = shear planes; 6 = economic mineralization/sub-economic mineralization. After CVRD Internal Rapport (Unpublished).

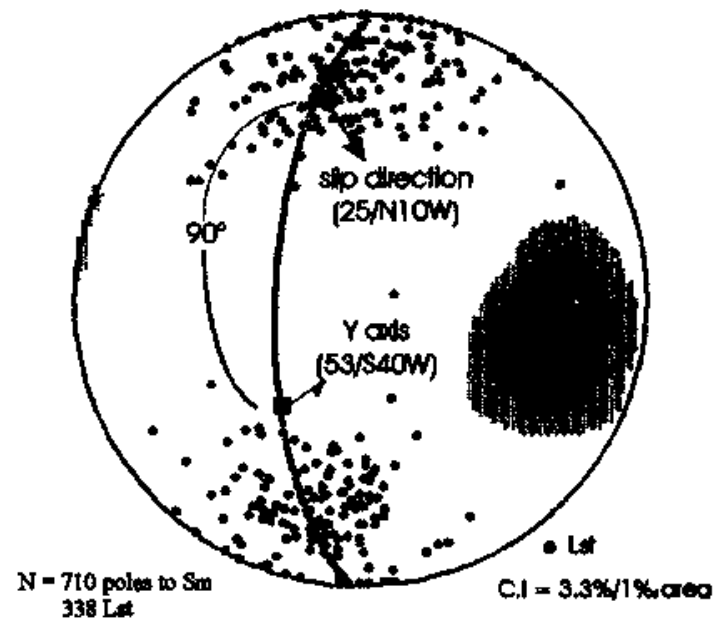

Figure 12 - Finite strain ellipsoid deduced for the FMP deformation zone. See text for discussion. characterize a sinistral strike-slip deformation generated by a dominant non-coaxial simple shear component within ductile-brittle to brittleductile domains; the anisotropy between the more competent rocks (dacites, diorites and gabbros) and the less competent ones (volcanics, tuffs and sediments) played an important role in the location of the shear zones.

2. The analysis of the kinematic indicators determine an oblate finite strain ellipsoid and slight to moderate tectonic deformation. The orientation obtained for $\mathrm{X}, \mathrm{Y}$ and $\mathrm{Z}$-axes are respectively $257 \mathrm{~N} 10^{\circ} \mathrm{E}$, $53^{\circ} / \mathrm{S} 40^{\circ} \mathrm{W}$ and $30^{\circ} / \mathrm{S} 60^{\circ} \mathrm{E}$.

3 . The veins are hosted mostly in shear-fractures, and to a lesser extent in extension fractures. The field relations and the internal deformation features of the veins indicate that they were formed or emplaced in different stages during the Dl deformation event. In almost all veins the filling is usually massive, but brecciated veins are also observed.

4. As the shear zones of the FMP district are considered as second order shear zones, parallel to the first order MSZ, the open spaces are rare and the orebodies have the tendency to be small.

5. The dilatancy was controlled by movement along irregular shear surfaces and fluid overpressing. The model of emplacement of the veins proposed for the area is analogous to the fault-valve model of Sibson et al. (1988): the brittle failure occurs when there is an increase of fluid pressure (Pfluid $\geq \sigma_{3}+T$ ). The discharge of the fluids through the shear fractures promotes a drop in fluid pressure. When the fractures are sealed the fluid pressure and the shear stress build up again, and the process recommence. The fluid pression, at least in one phase, exceeded the lithostatic pression in order to form the "flat" veins in the W Orebody.

6. In the FMP district the oreshoots display a tabular geometry, hosted along the fractures. This constitute the primary control of the mineralization. A secondary control is the stretching lineation (Lst), which reorientates the original tabular oreshoots parallel to its orientation.

7. Det alled surface mapping is necessary in order to characterize the dilatant sites (shear or tension fractures, axial plane of late folds and tension flat planes) and systematic mapping of the open pits in order to evaluate the degree of reorientation of the investigated orebody. The down dip extension of the orebody have to be investigated by different types of drilling programs, according to the structural model proposed for each orebody.

Acknowledgments This study is a part of a Ph.D. project, carried out by the first author. It was supported in part by a research grant from CAPES-Brazil/COFECUB-France. Financial support was also provided by the Departamento Nacional da Produfao Mineral (DNPM) of Brazil and CNPq. Logistic support was provided by the Companhia Vale do Rio Doce (CVRD), Rio Salitre Minera?ao (RSM) and Companhia Baiana de Pesquisa Mineral (CBPM) and their permission to publish is gratefully acknowledged.

\section{References}

Alves da Silva, F.C. 1995. Estudo Estrutural do Greenstone Belt Paleoproterozóico do Rio Itapicuru (Bahia): Importância dos Granites Sintectônicos, Controle das Mineralizações Auríferas e Evolução Transamazônica do Cráton São Francisco. In: Simpósio de Estudos Tectônicos, 5. Gramado 1995. Anais...Gramado, p. 331-333

Alves da Silva, F.C. \& Matos, F.M.V. 1991. Economic geology and structural controls of the orebodies from the Medium Itapicuru gold district: Rio Itapicuru greenstone belt, Bahia, Brazil. In: Ladeira, E.A., ed., Proceedings of Brazil Gold'91: The Economics, Geology, Geochemistry and Genesis of Gold Deposits, Belo Horizonte, Balkema, 629-635.

Borg, I. \& Handin, S. 1966. Experimental deformation of crystalline rocks. Tectonophysics, 3(4): 249-368.

Coelho, C.E.S, Faure, M., Prost, A., et Touray, J.C. 1990. Étude cinématique du champ aurifère de Fazenda Maria Preta (Bahia, Brdsil); Implications met alloge'niques. C.R. Acad. Sci. Paris, t.311, Série II: 977-984.

Coelho, C.E.S, Faure, M., Prost, A., et Touray, J.C. 1991. Kinematic study of the Fazenda Maria Preta gold deposit, Bahia, Brazil: Met allogenic Implications. In: Ladeira, E.A., ed., Proceedings of Brazil Gold'91: The Economics, Geology, Geochemistry and Genesis of Gold Deposits, Belo Horizonte, Balkema, 657-660.

Coelho, C.E.S. 1994. Genese des Fluides dans les Zones Deforméees et Mineralisées en Or de la Ceinture de Roches Vertes de Rio Itapicuru (Bresil): Gisetnents de Fazenda Brasileiro et Fazenda Maria Preta. Une Reconstitution basee sur I'etude des inclusions fluides dans leur contexte microstructural. Orléans. 330p (Doctor of Philosophy Thesis, Department of Earth Sciences of the University of Orleans).

Coelho, C.E.S. \& Ramboz, C. 1997. New Interpretation on the genesis of the Fazenda Brasileiro and Fazenda Maria Preta gold deposits, Rio Itapicuru Greenstone Belt, Bahia, revista de Ouro Preto - REM, 50 (4):42-53.

Colvine, A.C., Fyon, A.J., Heather, K.B., Marmont, S., Smith, P.M. \& Troop, D.G. 1988. Archean lode gold deposits in Ontario. Ontario Geological Survey Miscellaneous Paper, $139,210 p$.
Davison, I., Teixeira, J.B.G., Silva, M.G., Neto, M.B.R., and Matos, F.M.V. 1988. The Rio Itapicuru greenstone belt, Bahia, Brazil: structure and stratigraphical outline. Precambrian Research, 42: 1-18.

Freitas-Silva, F.H. \& Coelho, C.E.S. 1993. Controle Estrutural do Depósito de Ouro de Fazenda Maria Preta: Implicações para Prospeção Aurífera no Médio Itapicuru. In: Simpósio do Cráton do São Francisco, 2, Salvador, 1993. Anais...Salvador, SBG/SGM, v. 1, p. 327-330.

Gaal, G; Teixeira, J.B.G.; Silva, M.G.; Del Rey, J.M.H. 1987. New U-Pb data from granitoids reflecting Early-Proterozoic evaluation in Northeast Bahia, Brazil. In Proceeding of the Symposium on Granites and associated mineralization. Salvador, Bahia.

Hobbs, B.E., Means, W.D. Williams, P.P. 1976. An Outline of Structural Geology. John Wiley and Sons, ed ${ }^{\circ}$ de páginas

Hodgson, C.J. (1989a): The structure of shear-related, vein type gold deposits: a review. Ore Geology Rev., 4: 231-273

Hodgson, C.J. 1989b. Patterns of mineralization. In: Bursnall, J.T, ed, Mineralization and shear zones,. Geol. Ass. Canada, Short Course Notes , 6: 51-88.

Kishida, A. \& Riccio, L. 1980. Chemostratigraphy of lava sequences from the Rio Itapicuru greenstone belt, Bahia, Brazil. Precamb. Research, 11: 161-178.

Poulsen, K.H. \& Robert, F. 1989 Shear Zones and Gold: Pratical Exemples from the Southern Canadian Shield. In: Bursnall, J.T., ed, Mineralization and shear zones,. Geol. Ass. Canada, Short Course Notes, 6: 239-266.

Ramsay, J.G.(1980): The crack-seal mechanism of rock deformation. Nature, 284: 135-139.

Ramsay, J.G. \& Graham, R.H. 1970. Strain variations in shear belts. Can. J. Earth Sci., 7: 786-813.

Reinhardt, M.C. \& Davison, I. 1990. Structural and lithologic controls on gold deposition in the shear hosted Fazenda Brasileiro Mine, Bahia State, Northeast Brazil. Econ Geol., 85: 952-967 
Robert, F. 1992. The Structural Control of the Fazenda Maria Preta gold deposit. CBPM Technical Report, Unpublished.

Robert, F. 1990. The internal structure of the Cadillac tectonic zone southeast of Val d'Or, Abitibi Belt, Quebec. Can. J. Earth ScL, 26: 2661-2675.

robert, f. \& Poulsen, K.H. 1994. Diverse Gold Mineralization Styles in Canadian Greenstone Terranes. In: Simposio Internacional del Oro en Venezuela, 3. Caracas, 1994. Anais...Caracas, p. 111-122.

Rrobert, f, Sheahan, P.A.; Green, S.B. 1990. Greenstone Gold and Crustal Evolution. Proceedings of NUNA Conference...Quebec. Geological Association of Canada, $252 \mathrm{p}$

Sibson, R.H., Robert, F. \& Poulsen, K.H. 1988. High angle reverse faults, fluid pressure cycling, and mesothermal gold-quartz deposits. Geology, 16: 551-555.

Silva, M.G. (1984): A sequencia vulcano-sedimentar do Médio Rio Itapicuru, Bahia: Caracterizacao petrograTica, consideracoes petrogeneticas preliminares e zoneografiametam6rfica. In: $S \&$, P.V.S.V. \& Duarte, F.B., eds, Geologiaerecursos minerals do Estado da Bahia: Textos Básicos, Secret aria Minas Energia, Salvador, minerals do Estado da Bahia: Textos Básicos, Secret aria Minas Energia, Salvador, Brasil, 5: 06-42.

Silva, M.G. 1987. Geochemie, petrologie und geotektonische entwicklung eines Proterozoischen greunsteingnertels, Rio Itapicuru, Bahia, Brasilien. (Doctor of Philosophy Thesis, University of Freiburg)
Scares, A.S.B., Rocha, M.B., Oliveira, E.A.S. 1992. Novas idéias sobre os tipos de mineralização aurífera da faixa Antas-Maria Preta, Greenstone belt do Rio Itapicuru, Bahia. In: Congresso Brasileiro de Geologia, 37, Anais...SEG, São Paulo, v.1, p. 230-231.

Xavier, R.P. 1991. The role of microstructural and fluid processes in the genesis of gold-bearing shear zones: Fazenda Maria Preta Mine, Rio Itapicuru greenstone belt, Bahia, Brazil. 239 p. (Doctor of Philosophy Thesis, University of Southampton)

Yamakawa, T.; Almeida Filho, R.; Liu, C.C.; Derze, G.R.; Célio, B.; Pellon de Miranda, F.; Bentz, C.M.; Bueno, G.V.; Magnavita, L.P. 1994. Joint remote sensing study in northeastern Brasil. ERSDAC/INPE/DNPM/PETROBRAS, First Phase Report, $68 \mathrm{p}$

Manuscrito A-976

Recebido em 15 de abril de 1998

ReviSão dos autores em 25 de abril de 1998

ReviSão aceita em 28 de abril de 1998 